\title{
АНТРОПОЛОГИЯ ПИТАНИЯ
}

УДК 39

DOI: $10.33876 / 2311-0546 / 2021-53-1 / 238-259$

В.А. Липинская

\section{РУССКОЕ МАСЛОДЕЛИЕ (ТРАДИЦИИ, НОВАЦИИ И РАЗВИТИЕ ПРОМЫШЛЕННОСТИ) ХІХ-ХХ вВ.*}

Русское маслоделие развивалось в XIX-XX вв. как общенародное при участии всех слоев общества. Это позволило создать в стране промышленное производство высокого международного уровня. В статье рассмотрены последовательные периоды процесса.

1. Основу русского маслоделия составляли народные традиции получения масла из коровьего молока, имевшие этническую специфику. Она определялась особенностями климата с продолжительными зимами, на время которых прекращцалась лактация у рогатого скота, что требовало заготовки запасов продуктов. В крестьянском хозяйстве этим занимались женщины. Они владели разньми способами получения масла, в том числе - конечного продукта - топленого масла, проходивщего обработку жаром русской печи и приобретавшего возможность неограниченного срока хранения.

2. Инициатором развития товарного маслоделия являлся Н.В. Верещагин. Он ознакомился с технологией получения сливочного масла в сельских артелях разных государств и поставил иелью внедрить этот опыт в России для улучшения быта российского крестьянства. Преодолевая сопротивления чиновников и привлекая единомышленников, он открывал общедоступные школь и заводы маслоделия с использованием местного народного опыта.

3. Работа активизировалась в Сибири, где крестьяне владели большими стадами дойного скота. Важную роль играло создание Союзов маслоделов, которые организовывали артели, обеспечивали хранение и доставку товаров, устанавливали связи с международным рынком, на котором русское масло потеснило других экспортеров.

4. В советский период началось развитие маслоделия на государственном уровне. Организацию индустриального производства вели последовательно и многопланово: селекционная работа животноводов сочеталась с сохранением этнической специфики и укреплением традиционной базы молочного сырья, технические институты разрабатывали современное оборудование, соответственно улучшалось качество продукта, осуществлялось повсеместное поступление его в торговую сеть.

Ключевые слова: маслоделие, народные традиции, этническая специфика,

\footnotetext{
Липинская Виктория Анатольевна - д.и.н., ведущий научный сотрудник, Институт этнологии и антропологии РАН (РФ, Москва, Ленинский пр. 32-А). Эл. почта: vlipinskaya@yandex.ru

* Публикуется в соответствии с планом научно-исследовательских работ Института этнологии и антропологии РАН
} 
промышленное производство, преобразования советского периода

Ссылка при цитировании: Липинская B.A. Русское маслоделие (традиции, новации и развитие промышленности) XIX-XX в. // Вестник антропологии, 2021. № 1 (53). С. 238-259.

Промышленное маслоделие появилось в России только в конце XIX в. Оно так стремительно и успешно распространялось по стране, что к началу следующего века вышло на международный рынок и заняло первые места среди стран-экспортеров. Промышленное маслоделие возникло не в городах, а в сельской местности и опиралось на вековые народные традиции. Они мало изучены, так как масло-молочный промысел поздно приобрел товарное значение, а в повседневном быту жировые продукты животного происхождения использовались крестьянами крайне мало. Тем не менее, при экспедиционных наблюдениях в европейской части страны и в Западной Сибири удалось собрать сведения, раскрывающие историю народного маслоделия и его развития в промышленное производство.

\section{Традиции крестьянского маслоделия}

Основным источником для получения мягкого животного жира является молоко коров, а сам жир - масло называют коровьим (в прошлом - кравие). Молоко коровы употребляют в пищу преимущественно в свежем виде, а также - в вареном (кипяченое) или выдержанным в русской печи - топленылм, каждое из которых имеет свой вкус. Особенность молока заключается в том, что, простояв в посуде несколько дней, оно разделяется на слои (фракции), каждый из которых используется для получения новых продуктов. Верхний, более плотный слой - сливки снимают (сливают) и могут употреблять в пищу. При дальнейшем настаивании сливки закисают и превращаются в сметану, а нижнюю часть употребляют как простоквашу (простокишу). Сливки и сметану издавна использовали для получения масла, а из простокваши при желании делали творог.

При таком разнообразии продуктов, получаемых из молока, корова играла в хозяйстве крестьянина очень важную роль. Одна молочная корова могла дать в день два-три ведра молока и снабжала семью крестьянина пищей в течение года. Помимо молока корова оставляла на хозяйском дворе навоз, который применяли для удобрения полей, что повышало урожай. Поэтому богатство семьи в дореволюционной России определялось числом крупного рогатого скота и количеством выращиваемого хлеба.

Крестьяне держали коров как мясо-молочный скот. Селекционной работы в деревнях не вели, но она проходила естественным путем при отборе по молочности. Количество и качество молока непосредственно зависели от количества и качества корма. Летом коровы находились на «зеленых кормах» - на специально выделенных выпасах. Зимой их кормили сеном из сухих трав. В бедняцких хозяйствах нередко не хватало заготовленных кормов, тогда сено заменяли соломой, добавляли ботву картофеля, отходы от молотьбы и пр. В природных условиях на землях с хорошим травостоем (Архангельская, Вологодская губ.) выделилась холмогорская корова, имевшая примерно $3 \%$ жирности молока (по измерениям советского периода), и в Сибири с обширными свободными территориями, особенно на юге лучшей оказалась сибирская корова при жирности молока около 4\%. 
Традиции питания русского народа основывались на христианских представлениях и самоограничении. Все продукты разделяли на скоромные и постные (без использования животного сырья). По христианскому вероучению установлено в течение года несколько длительных постов и по два дня в неделю (среда и пятница). Благочестивые люди (особенно женщины) постились три дня в неделю (понедельничали), а кроме того брали обязательства поститься несколько дней при каких-либо событиях (в том числе при болезнях). Всего в году накапливалось более половины постных дней. За длительный период постов у крестьян скапливалось много молока и других молочных продуктов.

Молоко приятно на вкус и питательно, благодаря содержанию жира. Оно полезно, так как включает различные витамины, а кроме того обладает бактерицидными свойствами. Молоко и молочные продукты известны многим народам. С давнего времени велись поиски их сохранения на более длительный срок, но где и как впервые появилось масло остается неясным. Предполагается, что это происходило в южных странах: Индия, Иран, Турция, Израиль и по-видимому там, где перевозили молоко на большие расстояния. По современным наблюдениям, при перевозке молока в машине-молоковозе, в нее загружают доску. После доставки на место ее вынимают покрытую маслом (наблюдения автора в 1990-е годы, Московская обл., Алтайский край). Такая простота отделения жира дает основание предположить, что и в других регионах находили способы концентрации молока до конечного продукта - жировой эмульсии. Как считал

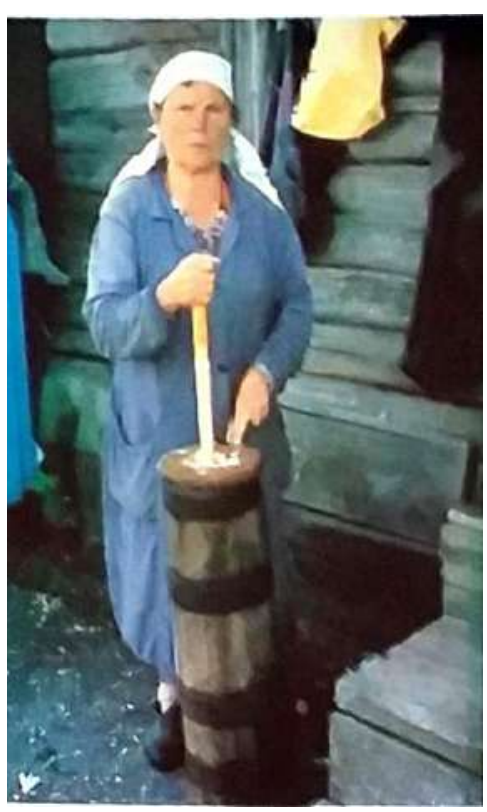

Рис. 1. Сбивание масла: 1) Пахтание в бондарной маслобойке (с. Желанное, Шацикий p-н, Рязанской обл.). Фото С.И. Иниковой, 1993 г.

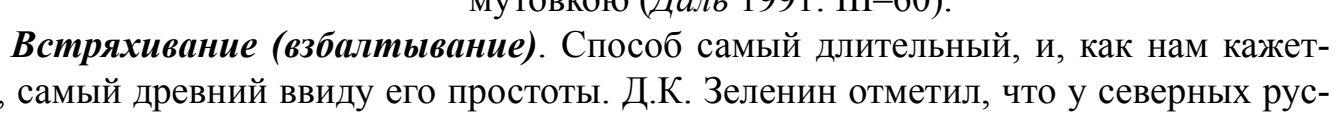

Встряхивание (взбалтывание). Способ самый длительный, и, как нам кажет-
ся, самый древний ввиду его простоты. Д.К. Зеленин отметил, что у северных русВ. Даль в русском языке название «масло» является
народным. Оно произошло от глагола мазать при переходе в подлежащее - «мазло», а затем путем замены в слове одной звонкой буквы (Даль 1991: II-305). В других странах Европы имеются традиционные обозначения этого продукта и оригинальные способы производства. В России известны несколько названий, способов получения и видов конечного продукта.

У русского народа изготовлением коровьего масла занимались женщины (бабье дело). Их задача заключалась в удалении из молока воды. Ее решали разными способами и получали три вида конечного продукта: из сливок делали сладкосливочное масло, из сметаны - кисломолочное масло, из того и другого при последующей обработке теплом - топленое масло. Все они бытуют и в настоящее время. Для маслоделия женщины создали утварь определенных форм, которую в прошлом сами лепили из глины. Полевые наблюдения позволили выявить конкретные детали пахтания - выделения масла из молока, из сливок и из сметаны. (Рис. 1). Как выяснил В.И. Даль в русском языке слово «пахтать» означало сбивать, сбалтывать, бить жидкость, встряхивая самый сосуд или мутовкою (Даль 1991: ІІІ-60). 
ских существовал обычай готовить к Пасхе небольшое количество масла. Для этого в кринку с плотно закрытым горлышком наливали свежие сливки и сильно встряхивали. В настоящее время иногда по медицинским показаниям требуется употреблять небольшое количество свежего масла. Его получают, встряхивая молоко в закрытых стеклянных бутылках. В 1993 г. при полевых исследованиях в Тамбовской обл. был выявлен не описанный ранее способ встряхивания в корчаге. Глиняный горшок имел форму амфоры, широко распространенной в прошлом в античном мире. Сосуд был высоким (примерно в полметра), с раздутыми боками, сужающимися к низу и плоским круглым дном. Довольно узкое высокое горло имело две вертикальные ручки и широкий ободок с обвитой вокруг него веревкой, образующей длинную петлю. Женщина сидела на сундуке, а корчага висела перед нею на крюке для люльки. Чтобы получить масло из молока или сливок приходилось долго встряхивать корчагу, взбалтывая содержимое. Местным краеведам этот способ не был известен в Тамбовском музее подобных сосудов не оказалось. В этнографической литературе о нем также не упоминалось. Однако известно, что в Киевской Руси X-XII вв. существовало производство амфорообразных корчаг. Как широко были распространены корчаги в Тамбовской обл. осталось не выясненным, но известно, что в заселении этой местности принимали участие выходцы с Дона и Левобережной Украины. Возможно ими были занесены некоторые элементы культуры Древней Руси (Зеленин 1991; Тамбовская энциклопедия 2004: 369; ПМА 1).

Сбивание масла рукой применяли в европейской части страны и в Сибири. Этот способ более длительный, но требует меньше усилий. Он основан на расслоении молока при отстаивании. Для этого молоко разливали в глиняные кринки - сосуды шаровидной формы с высокой горловиной. В каждом хозяйстве имелось много кринок: в европейской части страны их ставили по 10-15 штук сразу, в Сибири - 30-50 и более. В летнее время их опускали для отстаивания в погреб, там при низкой температуре, получали более толстый слой жира. При дальнейшем отстаивании, через несколько дней, сливки созревали, то есть закисали. Верхнюю часть - снимок перебрасывали в другой горшок, а в кринке оставалось обезжиренное (снятое) молоко. Горшки со сметаной затем ставили в теплую печь, чтобы ослабить сцепление между шариками жира, а потом выносили на холод (в ледник), где происходило разделение сметаны на фракции: более жирная часть собиралась вверху, а менее жирная сыворотка (сколотины, измятина, оденки, юрга) опускалась вниз.

В Вятском крае при экспедиционной работе в сельской местности, жители сообщали, что они сметану в печи оттапливают в широких горшках с рыльцем. После охлаждения верхний слой протыкают, сыворотка стекает и женщина начинает сбивать масло рукой, такими же движениями, как при подбивании теста. Д.К. Зелениным описан способ, применявшийся в средней полосе страны. Масло там сбивают (naxтают, мешают) такой же деревянной мутовкой - верхушкой ели (она же - колотовка, веселка), какой месят в квашне тесто. Обычно женщина садится на пол, ставит горшок с охлажденными сливками между ногами, мутовкой протыкает дырку и через эту дырку сливает сыворотку в отдельную посуду, а оставшееся в горшке содержимое сбивает мутовкой до тех пор, пока масло отделится от сыворотки (Зеленин 1991: 158-159).

Аналогично готовили масло в Ярославской губ. По описанию С. Дерунова, если использовали сливки, то их отстаивали в умеренно теплом помещении около 24 часов, а зимой - от двух до трех дней, иногда перемешивая. За это время сливки успе- 


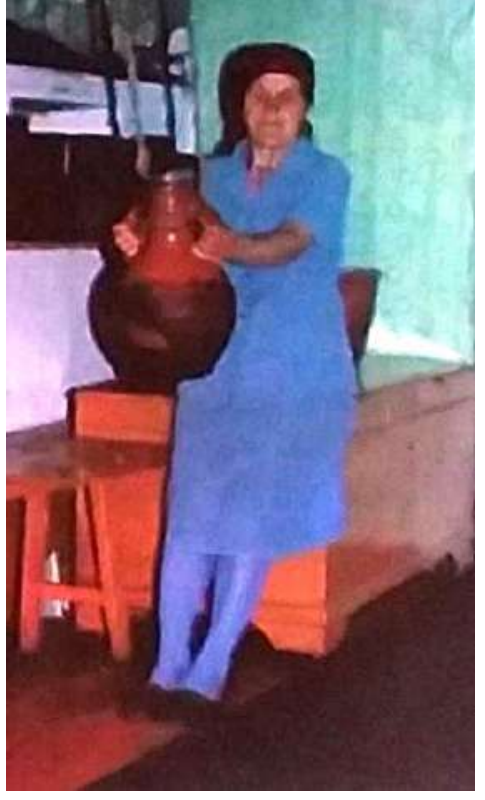

Рис. 2. Глиняная утварь для топленого масла

(с. Заливино, Кировская обл.). Фото С. Иванова, 1986 г.

вали скиснуть и загустеть. После сливания жидкости в другом невысоком горшке (комушнице) они легко превращались в масло (Дерунов 1877: 15).

В конце XIX в. при развитии бондарного промысла в Росси начали делать бондарные маслобойки, которые продолжают бытовать до настоящего времени. Они имеют вид высоких узких сосудов, слегка конусообразной формы. Через деревянную крышку с отверстием проходит длинный стержень - мутовка или поршень с диском. Благодаря этому женщины могли сбивать масло из сметаны стоя на полу в избе или на земле усадьбы. Возможно, появление бондарных маслобоек было стимулировано начавшимся развитием промышленного маслоделия и образцами применявшихся в нем аппаратов (Рис. 2).

Таким образом в XIX-XX вв. в европейской части России бытовали разные приемы получения масляного комка. В зависимости от основы, из которой он был добыт, масло определяли в торговые сети как сладкосливочное (из молока или свежих сливок) и кислосливочное (из сметаны). На северо-западе в районе Санкт-Петербурга в прошлом его называли финским или чухонским, а также - кухоннылм, так как из-за невысокого качества и дешевизны считали более пригодным в кулинарии. На остальной территории все эти виды имели общее обозначение - масло.

Полученный комок жира нуждался в доработке, для освобождения от сыворотки. Его помещали в глиняный латок или в деревянное корытце (ночва, сельница), где несколько раз промывали холодной водой и слегка отжимали, прокатывая по дну. Масло в свежем виде подавали к столу в миске по праздничным дням, или передавали для продажи. Еще в середине XX в. можно было видеть на рынках женщин, державших в руках желтоватые брусочки на капустных листьях (ПМА 2).

Свежее масло в крестьянских семьях употребляли как лакомство крайне мало, но жир входил в состав зимних запасов крестьян (бабий копеж), находившийся на попечении женщин. Для длительного хранения масло перетапливали, что продолжают делать и в наше время. Для этого промытые комки кладут в специальный широкий горшок с носиком (топнушка) и ставят в теплую русскую печь, после того как в ней испекут хлеб. Растопленное масло сливают в горшочки, кадочки или ведерки. На дне топнушки остается жидковатая масса (оденки, измятина, пахтанье). Ее используют в тесте для выпечки. Перетопленное масло называют топленка, а также - русское, оно является особенностью русской культуры, неизвестной соседям (Зеленин 1991: 159). Даже родственные народы - украинцы и белорусы сбитое и промытое масло складывают в бочки и солят для сохранения. В России масло топили издавна, так Н.А. Богоявленский, изучавший народную медицину, нашел документ, в котором указывалось, что уже в XV в. в Соловецком монастыре использовали различные молочные продукты: сливки, сметану, творог и сыр. Умели готовить топленое масло, которое называли красным, в отличие от пахтанья (сливочного масла). Оно входило в паек служилых 
людей и иногда использовалось при лечении больных (Богоявленский 1960: 42).

В сельской местности зимние запасы заготавливают и в настоящее время. При изготовлении масла несколько раз сливают жидкость, содержащую немало полезных и питательных веществ. Русские женщины все это используют в хозяйстве. Так, после снятия сметаны оставшуюся простоквашу ставят в печь, где она отстаивается. Затем откидывают на решето, или сливают в холщевый мешок, его подвешивают, чтобы стекала сыворотка, шедшая на корм скоту. Отжатую в мешке или на решете массу ставят под гнет для получения творога. Обра-

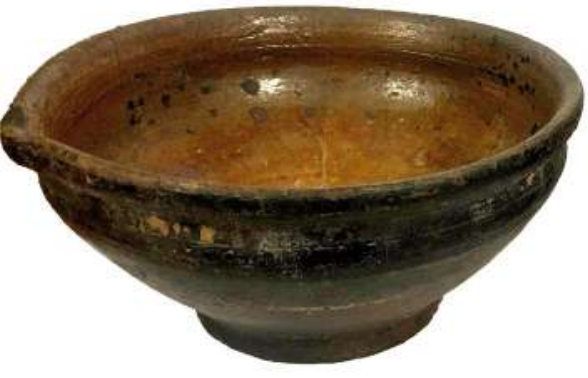

Рис. 3. Утварь для домашнего маслоделия в Архангельской обл.: Гончарная топнушка с рыльщем Фото Т.А. Ворониной, 1991 г. ботка молока, приводящая к получению из него ряда новых продуктов демонстрирует рациональность крестьянского хозяйства и умение русских женщин создавать разнообразную кулинарию даже при наличии хотя бы одной коровы. (Рис. 3).

\section{Маслоделие в Сибирском регионе}

В Сибири молочно-масляное дело развивалось по русским же народным традициям, но в иных условиях. Заселение новой территории проходило, когда коренное население было малочисленно и очень разрежено. Поэтому имелось много свободных невозделанных земель. Пока налаживалось хлебопашенное хозяйство, скотоводство успешно существовало, сибирские крестьяне были намного лучше обеспечены, в том числе и крупным рогатым скотом. Если в европейской части страны бедным считали хозяйства с одной коровой или вообще без скота, то в Западной Сибири к бедным относили семьи с тремя-четырьмя коровами. Соответственно, сибиряки были хорошо обеспечены молоком. Первые засельщики, пришедшие из северных губерний, принесли древние способы переработки, которые затем самостоятельно развивали. Основные действия по получению масла, определявшиеся самой природой продукта, были одинаковы по обе стороны Урала, в деталях же производства наблюдались местные особенности.

Для Тобольской губернии основные способы изготовления масла описал местный маслодел В.Ф. Сокульский. По его сведениям, после дойки коров молоко обычно разливали по кринкам, а в Курганском округе - по латкам (глубоким мискам, как бы тазикам - В.Л.). Их ставили в прохладном месте на три-пять дней, пока «по сядет» простокваша. Тогда хозяйка одним пальцем обводила по краю, чтобы отделить жировой слой сметаны и тремя пальцами, или ложкой сбрасывала сним в другую большую кринку или латку. Затем сметану, по местному пенки, в кринках ставили на протопленную печь, чтобы пенки поднялись (больше закисли). Тогда их выносили на холод и из остывших «спускали (сливали) сыворотку», затем в тех же кринках или латках сразу начинали сбивать рукой или мешалкой. Полученное масло ставили в печь не жаркую, чтобы оно растопилось и отстоялось, в нем сверху снимали пленку с выступившей грязью, масло разливали в малые кринки, остуживали и убирали для хранения на зиму (Сокульский 1896: 3). 
В южной части Западной Сибири, на территории бывшей Томской губернии масло получали из молока или сметаны. В этой части региона в XX в. проводили наблюдения этнографы (Алтайский край, республика Алтай, ВКО). При полевых выездах женщины сообщали этнографам о современных способах получения масла и о досоветском времени. Во второй половине XX в. готовое масло можно было купить в торговой сети, но прежние навыки сохранялись и пожилые женщины нередко сбивали его сами. Так, жительница с. Ново-Алейского Анна Тихоновна Петрова сообщила, что в семьях сибиряков держали возле дома по нескольку дойных коров, а недоившихся отгоняли в горы на заимки. В пост собирали много молока. Его заготавливали на зиму разными способами. Из свежего сбивали масло в маслобойках, откуда его надаивали много. Заливали в маслобойку ведра по три, но получалось мало и это было не выгодно. Больше делали масло из сметаны, оно лучше по вкусу. «Молоко разливали по кринкам. Их всегда было много, штук по 30. Их ставили в погреб и держали дня по три, пока не насобираешь ведер семь сметаны. Потом натопишь печь, и оттомишь в печи после хлеба. Выносишь на холод, с час остывает. Тогда проткнешь сметану, воду сольешь и сбиваешь рукой или веселкой - получается сливочное масло» (ПМА 3: Петрова).

В Сибири со времени заселения по многу коров держали старообрядцы, при этом они постились очень много дней в году, отчего скапливались большие излишки молока. Как вспоминала жительница с. Волчно-Бурла (ПМА 4: Горбунова). «При 11-12 коровах каждый вечер занимали под молоко до 50 кринок. Сметану сбивали обычно рукой в деревянной кадушке-сбоечке. С одной коровы за год получали больше 20 кг масла». (ПМА 5: Горбунова). Российские переселенцы, приезжавшие в конце XIX в. поражались тому, что у сибиряков стояли кадки, полные топленого масла. Его не успевали съедать, оно плесневело и даже заводились черви. У переселенцев запасы были скромные. Татьяна Матвеева из с. Заркалы тоже делала масло из сметаны, но немного: «Небольшое количество ее насобираешь, - рассказывала она, - и в глиняном горшочке ставишь в печь. Оттомив, остуживали, чтобы в верху отстоялась пенка (сметана), ее протыкали, жидкость сливали и били рукой, ложкой или

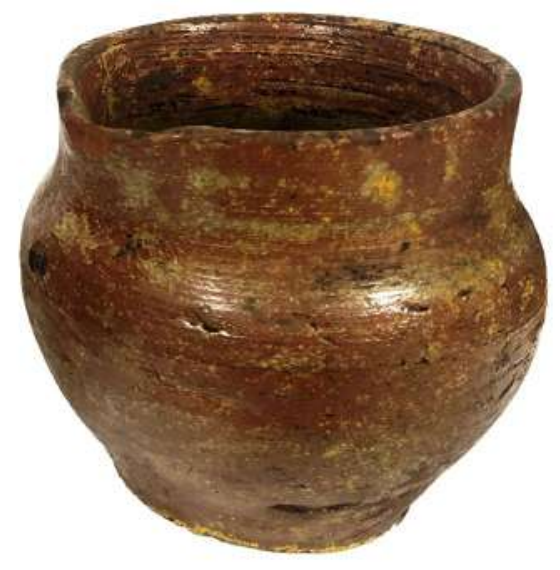

Рис. 4. Глиняная утварь для топленого масла: Горшочек для хранения масла (с. Заливино, Кировская обл.). Фото С. Иванова, 1986 г. мутовкой. Только помешаешь - и масло готово. Если масла заготавливали много, то сметану заливали в сбойку - кадочку с крышкой, в которую вставляли деревянную мутовку. Потом масло перетапливали, оно могло храниться в прохладном месте много лет». (ПМА 6: Матвеева).

Помногу масла скапливалось в деревнях старообрядцев-каменщиков, живших на самом юге Западной Сибири в Алтайских горах (в настоящее время - территория Казахстана). В 1930-х года там проводили наблюдения этнографы Б.Э. Бломквист и Н.П. Гринкова - участники Казахстанской экспедиции Академии наук. По их сведениям, в 1920 г. в деревнях было много семей, державших до 25 дойных коров, ко- 
торые свободно ходили в поскотине (ограждение лугов вокруг селений) на вольных кормах. Уход за скотом был весьма примитивный, не имелось даже теплых дворов, но горный воздух и обильные корма на альпийских лугах, а также сотни коров обеспечивали большой удой. Как обычно молоко для отстаивания разливали в кринки, которых в крупных хозяйствах скапливалось до 600 штук. Снятую сметану «сбрасывали» в кадушку-сбоечку и сбивали бузгали кистью руки в одном направлении. Если сметаны накапливалось очень много, то в одной кадке сбивало ее несколько женщин. По мере бузгания начинали комиться - скатываться комочки масла. Их собирали и перетапливали в горшках для хранения и продажи (Рис. 4).

Лишь в 1920-х годах в горах стали появляться маслобойки местного варианта туяски с пером - долбленые кадочки, в крышку которых вставляли как поршень мутовку - стержень с разветвлениями на нижнем конце. Мутовки использовали также при замешивании теста. Их вырезали мужчины из верхушки молодых порослей ели, кедра или других хвойных деревьев. Примерно в эти же годы появилось другое местное изобретение - болтушки или сбойки - маслобойки, которые устанавливали в русле быстрых и мелких горных ручьев и речек. (Бухтарминские... 1930: 110-115). Одно из таких устройств нам удалось увидеть в 1990-м году в с. Верх-Уймоне. В реке была укреплена недалеко от берега бочка с горизонтальными лопастями на оси. Они приводились в движение струящейся мимо водой, когда снимали запирающее устройство. Эти механизмы повторяли старинные толчеи - небольшие мельницы с XVIII в. использовавшиеся сибиряками на мелких реках южного Алтая для переработки зерна в муку и крупу. Маслобойки, болтушки и толчеи являлись вариантами традиционных мельниц, приспособленных в местных условиях для сбивания масла и перемалывания зерна.

Также и способы использования молока стали в Сибири разнообразнее. Сибиряки научились замораживать зимой молоко, как морозили рыбу на севере региона, и также делали строганину. Это позволяло увеличить срок использования продукта и вводило новое лакомое блюдо. При надобности мороженое молоко оттаивали в помещении и сдабривали сливками или сметаной. Такая строганина являлась лакомством, но при желании растопленное молоко можно было использовать для получения масла или приготовления с ним каких-либо блюд (каши, сырники и пр.).

Приведенные примеры показывают, как легко русские крестьяне пополняли и разнообразили кулинарию путем собственных находок, а также перенимая от других народов.

\section{Развитие промышленного маслоделия}

В конце XIX в. в России начало развиваться промышленное маслоделие, имевшее в основе народный опыт. Масло домашнего производства со второй половины XIX в. уже получило спрос на внутреннем рынке. Перекупщики (прасолы) скупали его от крестьян, распространяли через ярмарки и частично вывозили за рубеж, также поступало в торговую сеть и импортное масло от западных соседей.

В Западной Европе к этому времени уже действовали масломолочные заводы, сложились этнические традиции и определился круг стран, участвовавших в мировом экспорте. Для рекламы своей продукции они устраивали выставки, где демонстрировали сорта масла и инвентарь для его производства. Самые крупные промышленные выставки проходили в Париже, для осмотра которых приезжали и россияне. Интерес русских помещиков к сельскохозяйственному отделу выставок 
был неслучаен. После отмены крепостного права землевладельцы были озабочены повышением доходности своих хозяйств. Так молодой лейтенант морского флота, сын помещика из Череповца Н.В. Верещагин заинтересовался молочной промышленностью. Он обратил внимание на нежный вкус французского масла, которое делали из подогретых сливок и на хорошую организацию работы на молочных фермах Дании. От этого государства была организована поездка интересующихся на фермы страны для наглядной демонстрации производства (Гутери 2011: 16-52).

В Дании Н.В. Верещагин ознакомился с работой мастеров, рассмотрел механизмы, использовавшиеся для ускорения и улучшения маслоделия. Он посетил также музей крестьянского быта и был поражен разницей между бытом крестьян в начале XIX и тем, что наблюдалось в конце его. «Мне было горько и обидно за нашу страну. В России земли лучше и обширнее, а крестьяне живут хуже». Было очевидно, что в стране необходимо организовать помощь нашим крестьянам в улучшении породности коров и переходе от крестьянских способов сбивания к современным европейским. Тем самым Н.В. Верещагин взялся за решение грандиозной проблемы общегосударственного значения: улучшения быта российского крестьянства, чему и посвятил всю жизнь. Его деятельность была досконально рассмотрена и отражена в специальной публикации историка А.В. Гутерца «Н.В. Верещагин. На благо отечества» (Гутери 2011). Заручившись консультацией зарубежных специалистов и изучив литературу, Н.В. Верещагин в 1866 г. на свои средства и при поддержке ВЭО организовал в с. Отроковичи Тверской губернии первую в России крестьянскую сыроварню. Это был опыт работы с молоком, давший хорошие результаты. Маслоделие и сыроделие по характеру производства тесно связаны между собой, и в дальнейшем они сопутствовали друг другу.

В первую очередь необходимо было пробудить интерес крестьян и познакомить их с практикой зарубежного молочного хозяйства. Н.В. Верещагин обращался в ВЭО с просьбой о выделении земли для организации школы молочного дела, писал письма в земства и министерства. После многократных запросов ему была предложена земля общины с. Едимоново Корчевского уезда Тверской губернии, в поместье барона Корфа. Ко времени приезда Верещагина в селе насчитывалось около 100 дворов и свыше 600 жителей, стояла церковь, был постоялый двор, четыре молочные лавки и три кузницы. Село находилось на левом берегу Волги, община крестьян имела небольшое стадо, выход на заливной луг, а помещик также содержал стадо молочных коров в 70 голов. Общего ежедневного удоя хватало для начала работы по молоко- и сыроварению. При поддержке Тверского и Ярославского земств, Петербургского собрания сельских хозяев и других ведомств удалось получить на обустройство и содержание школы ссуду Министерства финансов и 15000 руб. в год на 6 лет. Деньги переводили Тверскому губернскому земству, перед которым требовалось отчитываться за все затраты. Их было немало. Приобретали лучшие образцы оборудования за границей, по зарубежным образцам строили здания из русского леса, но часть материала необходимо было закупить - например, буковые клепки для бочек, которые считались лучшими на Западе.

Школа задумывалась для крестьян, но при составлении программы определили, что принимать будут лиц обоего пола и всех сословий не моложе 18 лет. Среди крестьян могли поступать неграмотные, поэтому в состав служащих включили учительницу, а также семь приглашенных мастеров по всем видам производства, которых позже сменили выросшие свои специалисты. Школа в Едимоново просуществовала 
почти 20 лет. За это время поступило 367 человек. По сословиям ученики распределялись так: 25 дворян, 204 крестьян, 62 из другого звания, 15 разночинцев, прочие мещане. Занятия проводились в течение года для грамотных и двух лет - для неграмотных. За это время подробно изучали всю практику, необходимую скотоводам: повседневный уход за животными, выпаивание телят, доение коров и даже откорм свиней. Непосредственно по молочному делу: уход за молоком, приготовление сливок, сметаны и творога; затем - сгущение молока, приготовление масла из свежих сливок, голштинское маслоделие, а также способы сыроварения различных сортов. Для закрепления знаний осуществляли выезды в страны, имевшие школы.

Одна русская школа не могла преобразовать маслоделие в стране, поэтому Н.В. Верещагин добивался распространения обучения и создания передвижных показательных маслоделен. Первая из них появилась в 1886 г. в Вологодской губернии, а через несколько лет там был открыт завод постоянного действия, работавший по французскому методу. Н.В. Верещагин несколько изменил его, пытаясь найти свой вариант с использованием народных традиций. Он стал перетапливать сливки, как крестьянки перетапливали молоко и масло. Пастеризованные сливки придавали маслу своеобразный ореховый привкус. Новый сорт получил высокую оценку в России, а также и за рубежом, куда вывозили часть продукции под названием «петербургское» или «парижское». Успехи дела побудили Н.В. Верещагина и его друзей принимать участие в российских выставках в целях рекламы (Вологда, Пошехонье, Москва). В столице в 1882 г. проходила Всероссийская художественно-промышленная выставка, где была представлена работа маслодельных школ и заводов, а также демонстрация самого процесса производства. Он был показан при сравнении деревенского способа сбивания руками в избе и заводского с машинами, на которых работали молодые ученицы в красивой одежде, что служило наглядной агитацией.

В конце XIX в. в России появились в продаже новые образцы компактных механизмов для маслозаводов по ценам, доступным даже для людей со средними доходами. «Cепараторы де Лаваля» для быстрого отделения сливок вскоре получили признание у русских предпринимателей. Зарубежные маслобойки систем «Лавуазье» и «Дюркона» действовали разными способами сбивания: вертикальные толкачныле в виде цилиндров с двигающимся внутри вверх-вниз поршнем и горизонтальные с закрепленным внутри валом, на котором крепились лопасти, при вращении бившие по налитой жидкости.

Новые механизмы ускоряли весь процесс получения масла и тем самым открывали пути к развитию товарного производства. Хотя полное оборудование заводов требовало значительных затрат, но, как показывал опыт, они быстро окупались. Например, один из учеников школы маслоделия смог открыть в Вологодской губернии, скупая молоко по деревням, один за другим пять заводов масло- и сыроделия. Русские мастера из крестьян по образцу зарубежных маслобоек начали делать свои, используя народные традиции. За основу были взяты бондарные бочонки двух форм. Вертикальный вариант бочонка слегка зауживали кверху. В крышку вставляли стержень-мутовку по образцу использовавшихся женщинами для замешивания теста, взбивания киселей и пр. Образцом для горизонтальной маслобойки послужил лагун для кваса, лежащий на боку с квадратной крышкой сверху. Внутри укрепляли горизонтальный стержень (деревянный или металлический) с дощатыми лопастями и с рукояткой для вращения, выведенной через боковую стенку. Такие маслобойки 
получили повсеместное распространение в XX в., ими пользовались, их экспонировали в музеях и предъявляли этнографам как традиционные. Благодаря дешевым самодельным механизмам товарное маслоделие стало доступно крестьянам.

В деревнях под местные заводики приспосабливали традиционные дома. Небольшие маслодельни оборудовали в избе, где делали полки, ставили лавки и скамейки, на которых размещали ушаты для отстаивания молока. В летнее время устраивали холодный отстойник в подполье, углубляя его. Охлажденные сливки сбивали в маслобойках за 1-2 часа. Пахту сливали, масло промывали два-четыре раза и отжимали на столе скалкой. При этом часть полученного подсаливали, подсыпая из горсти (1,5-2 фунта соли на один пуд масла), другую часть перетапливали в печи. Для заводов покрупнее выделяли отдельные здания. Так, в Пошехонском уезде Ярославской губернии в конце XIX в. действовал 31 завод, из них в нежилой избе размещалось 9, в доме заводчика - 16, в особом строении - 2, в арендованном помещении - 1 , в артельном здании - 3 (Дерунов 1877: 11-17). В пятистенках выделяли три отделения: 1 - приемную с котлами для воды и нагревания молока, 2 - аппараторную с маслобойками, 3 - обработочную с прессом и бондарными ушатами для заквашивания сливок (Снегирев 1906: 510). В большинстве заводов сливки собирали в маленькие ушатики, выносили в холодное место и постоянно помешивали для скорейшего охлаждения, затем заквашивали. Снятое молоко тоже разливали по ушатам и раздавали крестьянам. Готовую продукцию упаковывали в бочки ольховые (не изменяющие запаха) или в дубовые (придававшие крепость содержимому) для отправления в Москву и Петербург. Как отметил П. Иванов, в северорусских губерниях большинство заводов были крестьянскими артельными. Помещики открывали немного заводов, и преимущественно сыроваренных. Продажная цена сыра была выше и, соответственно, доходность предприятия больше (Иванов 1895: 5-9).

Иные условия производства масла и сыра складывались за Уралом.

\section{Товарное маслоделие в Сибири}

В Сибири, сравнительно с европейской частью, было много свободной земли и хороших пастбищ, поэтому крестьяне держали много скота, в том числе коров, и были хорошо обеспечены молочными продуктами. Во второй половине ХХ в. в связи с переселением массы крестьян из европейской части страны появилось много рабочих рук, что вызвало активизацию хозяйственной деятельности как в земледелии, так и в скотоводстве. Крестьяне издавна излишки заготовок масла отправляли для продажи на ярмарку. Прибытие переселенцев из разных губерний страны не привело к изменению способов получения масла, так как традиция была едина для всего русского народа. Увеличение населенности лишь способствовало большему выходу товарной продукции. Сохранявшийся примитивный способ настаивания молока в кринках, сбивания в горшках руками и перетапливания в печи не мог улучшить качества, но рынок принимал любой товар.

Деревенское масло скупалось прасолами на мелких ярмарках или выменивалось на товар по деревням. С мелких ярмарок и от мелких скупщиков оно попадало на более крупные ярмарки к крупным оптовикам, характерным для сибирской торговли того времени. Оптовики перетапливали скупаемое масло, комбинировали крупные партии и сбывали их на Ирбитской и Нижегородской ярмарках, пересылали в Москву 
и Петербург, на юг России и оттуда за рубеж, в частности в Турцию. В торговле его называли сибирским топленылм маслом. На ярмарках скупавшийся товар разделяли на категории: набивное - купленное и без переработки набитое в бочки; наливное - перетопленное заново, отстоенное и очищенное от всплывшего мусора; колобковое - также перетопленное, разлитое по формам и в остывшем виде поступавшее в продажу без тары, в виде колобов.

Откликаясь на запросы рынка, сибиряки год от года увеличивали выделку масла. Разбогатевшие старожилы, используя рабочую силу переселенцев, стали массово открывать заводы, а молоко собирали от односельчан. Как рассказывали сибирячки, при заводях выделяли приемную, которую в народе называли молоканка. Туда женщины относили молоко в ведрах, обычно от вечерней дойки. Утреннее разливали по крынкам, штук до полсотни их отстаивали в погребах (ПМА 8: Лопатина). (Рис. 5).

В 1894 г. частный предприниматель привез в Сибирь первый сепаратор и открыл два завода. Появление нового механизма не только ускоряло отделение сливок, но и увеличивало их выход. Для сибиряков был открыт

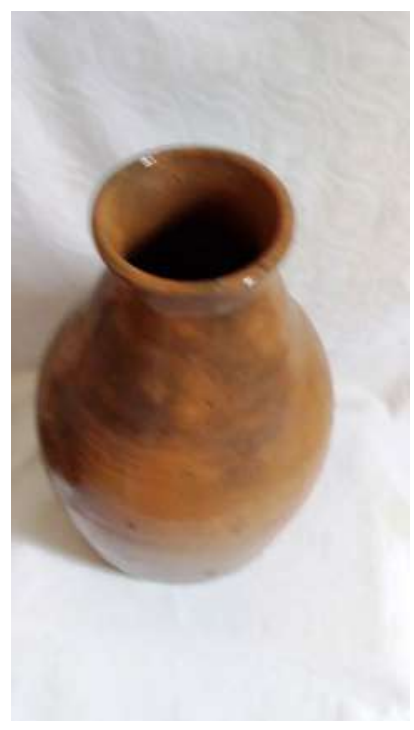

Рис. 5. Глиняная утварь для топленого масла: Корчага (с. Кольванское, Алтайский край). Фото В. Липинской, 1980 г. новый способ получения масла без заквашивания молока - так называемого сладкосливочного. Удачный опыт использования сепараторов стимулировал развитие в регионе маслоделия. Начали стихийно создаваться крестьянские артели маслоделов, сходные с традиционными сельскохозяйственными супрягами, товариществами и пр.

Нередко крестьянам возвращали с заводов сыворотку после отсепарирования молока (oбраm). Это было выгодно для крестьян, так как хозяйки делали из него творог, добавляли в тесто, использовали для корма скота. На отходах маслоделия стало развиваться свиноводство. К 1896 г. насчитывалось уже 15 частных заводов и несколько кооперативных. Из Сибири вывозили до 8 тыс. тонн масла (Маслоделие 1932: 310).

В 1901 г. состоялась первая выставка произведений маслоделия на территории Сибири в г. Кургане, и одновременно проходил съезд молочных заводов и деятелей по оценке качества масла, его надежности в хранении. Сибирское масло эксперты хвалили за «сухость и прочность», но нарекания вызвало наличие «мусора» - неряшливость на всех стадиях производства и закисление сливок «самоквасом». Быстрое увеличение сибирского маслоделия и его выход на экспорт привлекли внимание правительства. В марте 1902 г. на заседании Государственного совета и Комитета министров прошло «Особое совещание о развитии маслоделия в Сибири», и более того, на следующий год для маслоделов было выделено из дохода Государственного казначейства 160 тыс. рублей, которые потратили на содержание школ и лабораторий, оплату инструкторов и пр. (Гутери 2011: 48-122).

Поднимать уровень сибирского маслоделия было поручено Н.В. Верещагину. Он привлек своего лучшего ученика В.Ф. Сокульского. Поляк по происхождению, он окончил земледельческое училище на родине, в Могилевской губернии, и проходил практику в Едимоновской школе молочного хозяйства. За время работы он несколь- 
ко лет служил заведующим министерской передвижной школы маслоделия в Смоленской губернии и одновременно принимал участие в подготовке и проведении выставок по молочному хозяйству. Существенно, что, имея практические навыки и опыт подготовки специалистов, В.Ф. Сокульский, как и Н.В. Верещагин, ставил своей основной целью улучшение жизни крестьян. Его активная работа в Сибири началась с пропаганды необходимости преобразований по нескольким направлениям: улучшение породности коров, условий содержания и кормовой базы, а в целом подъема культуры производства. Как и в европейской части страны, в Сибири начали открывать школы и заводы.

Однако крестьяне первое время относились к маслозаводам с большим недоверием и подозрительностью. В неурожайные годы или при эпизоотиях возникали настоящие молочные бунты - население разбивало заводы, ломало сепараторы и т. д. Но преимущества машинной переработки молока скоро стали очевидными. К 1900 г. в Западной Сибири действовало уже более 1000 маслозаводов, из них около 30 были кооперативными, остальные - частных предпринимателей. Важную роль в ускорении темпов производства сыграло открытие Великой Сибирской железной дороги. В регион хлынул поток всякого рода промышленников и торговцев. Растущий капитализм покрыл Сибирь разветвленной сетью контор по скупке сырья и продаже сельскохозяйственных машин и орудий. В числе торговцев было значительное количество иностранцев, скупавших у крестьян масло и продававших сепараторы и полное оборудование для маслозаводов. Продажа производилась в кредит, что облегчало развитие маслозаводов, но и закабаляло население.

В кредит брали молоко не только у иностранцев. Например, в с. Шемонаихе на юге Алтайского края маслодельный завод появился в 1904 г. при объединении средств трех местных купцов. Через несколько лет их кооперация распалась и каждый открыл свой завод. Началась борьба за поставщиков. Чтобы закрепить крестьян за заводом, каждый владелец продавал им в кредит потребительские товары, чем загонял в долги. В ответ крестьяне создали свою кооперацию по сбыту. «Нас было 20 человек, - рассказывал А.А. Авдеев. - Мы заключили договор о вывозе масла к железной дороге в г. Семипалатинск» (ПМА 9: Авдеев). Явная доходность маслоделия вызвала массовый рост кооперирования в разных формах. Даже при учете только заводов к 1907 г. насчитывалось 700 кооперативных и более тысячи частновладельческих. Однако неподготовленность крестьян к организации общего производства, неквалифицированность саморощенных мастеров и раздоры при распределении доходов вызывали дробление артелей, что приводило к ухудшению качества масла. К тому же, для приобретения оборудования крестьяне нуждались в деньгах и искали источники ссуд и кредитов.

Как и в европейской части страны, в Сибири действовали отделы Московского общества сельского хозяйства, которое давало консультации по скотоводству и маслоделию, а также - помогало с финансами. Западносибирский отдел Общества находился в г. Кургане. Его председатель А.Н. Балакшин ежегодно проводил конкурсы маслоделов с выдачей премий, чтобы стимулировать повышение качества продукции. В 1901 г. в Кургане состоялась первая Выставка продуктов маслоделия с одновременным Съездом заводчиков и деятелей по молочному хозяйству, на которых были оценены общие успехи и качество работы отдельных заводов. В заключение от имени участников Съезда были направлены письма в различные государственные 
учреждения, в которых сообщалось о положении сибирского маслоделия, а также ходатайства о пособиях. Правительство приняло во внимание затруднения сибиряков, и в 1903 г. Государственный Совет выделил из фондов казначейства огромную сумму в 160 тыс. руб. на непредвиденные расходы. Деньги были использованы для открытия новых школ, подготовки мастеров и инструкторов, создание лабораторий по качеству масла и пр.

Начало XX в. стало временем беспримерного вовлечения крестьян в маслоделие, роста как частных заводов, так и артелей. В 1907 г. на собрании заводчиков и уполномоченных ряда артелей было принято решение о создании Союза сибирских маслоделов первоначально для совместного приобретения сельскохозяйственных орудий, для получения ссуд и сбыта продукции. Практическая деятельность Союза постоянно расширялась: привлечение новых участников, оказание помощи ссудами и оборудованием, открытие школ и заводов, строительство лабораторий. Были созданы маслохранилища, налажены пути транспортировки, расширены торговые и экспортные связи. Союз закупал за рубежом буковые клепки для бочек, необходимые для вывоза продукции. Нагляднее всего отражало успехи сибиряков увеличение выхода масла и успехи вывоза продукции. Так, в 1901 г. только по железной дороге было перевезено 17,6 тыс. тонн масла, а в 1907 г. - 526 тыс. тонн (Маслоделие 1932: 311, 323). Самая яркая оценка сибирского маслоделия содержалась в докладе императору от П. А. Столыпина и А. В. Кривошеина, в котором сообщалось, что «вывоз масла дает больше золота, чем все сибирские золотые прииски вместе взятые» (Гутери 2011: 182).

Однако развитие производства по капиталистическому пути улучшало быт в первую очередь старожилов, но с конца XIX в. в Сибирь прибыла масса необеспеченных переселенцев из европейской части страны. Им приходилось заново налаживать хозяйство, и лишь немногие имели возможность открыть завод, большинство же становились работниками. Каждый из переселенцев стремился купить в первую очередь корову для прокорма семьи, они же и сдавали молоко. Как вспоминала М. Демченко из переселенческого пос. Горьковского: «Родители приехали, корову купили, а молока не видали, все на молоканку сносили» (ПМА 10: Демченко).

На огромной территории Западной Сибири развитие маслоделия не могло проходить равномерно и единообразно. Полевые наблюдения этнографов показали, что и среди сибиряков-старожилов заводское производство масла сосредотачивалось преимущественно вблизи налаженных путей сообщения. Чем глубже в леса, тем позднее туда проникала техника. Даже распространение сепараторов затягивалось до 1930-х годов (Бардина 2009: 267; Бухтарминские... 1930: 111). Поэтому на внутренний рынок поступало масло, весьма различавшееся по качеству. Союз сибирских маслоделов организовывал его передачу на крупные заводы, где вся продукция проходила переработку для соответствия международным нормам. Им были налажены также связи с соседними странами. В 1913 г. по инициативе А.Н. Балакшина было организовано в Лондоне товарищество «Юнион» в составе Союза сибирских маслоделов, крупной английской фирмы и др.

Внутри страны транспортировка масла шла гужевым транспортом к железнодорожным станциям, и оттуда оно по железной дороге вагонами переправлялось к таможенным центрам. Особое значение имело создание специальных вагонов-холодильников. Их красили в белый цвет как сигнал для движения без задержки. Благодаря этим улучшениям Сибирь стала основным экспортером русского масла. За 
рубежом белые вагоны получили название «Белый лебедь Сибири». На внешнем рынке сибирское масло ценили за натуральность, хорошую консистентность, высокую жирность и сухость (малое содержание воды). Мировой импорт масла в то время делили между собой в основном Англия и Германия, которые концентрировали более $90 \%$ всего мирового ввоза. Перед I мировой войной 1-е место импорта в Англию занимала Дания (свыше 40\%), 2-е принадлежало России. В Германском импорте на 1-м месте стояла Россия (55\% ввоза), с началом империалистической войны экспорт масла из России стал сокращаться (Масляная... 1932: 327). Одновременно в связи с осложнениями во внешней политике и в социальной жизни народа маслоделие в стране приходило в упадок. Так, в 1913 г. вывоз из Сибири составлял 72,7 тонн, а в 1917 - всего 57,2 тонны. Были нарушены прежние взаимосвязи производства и потребления, импорта и экспорта.

\section{Изменения в советский период}

Начало XX в. принесло русскому народу ряд драматических событий, которые ослабили и частично разрушили многие стороны налаженной ранее хозяйственной жизни, в том числе пострадало маслоделие. Так, в 1913 г. в России было выработано 104 тыс. тонн масла и из них экспортировано свыше 79 тыс. тонн, а в 1920-е годы производство сократилось до 69 тыс. тонн, при отсутствии экспорта. Союзы и другие объединения маслоделов в европейской части и в Сибири прекратили существование. Для революционных активистов все заводчики, независимо от их социального статуса, являлись представителями буржуазии и подлежали экспроприации, по ходу которой были разрушены более крупные и лучше механизированные предприятия. Период борьбы с кулачеством обернулся развалом крупных скотоводческих хозяйств. Животных массово уничтожали, сохранившуюся часть распределяли по семьям бедняков, тем самым разрушая построенную ранее базу обеспечения заводов молочным сырьем.

В этих сложных условиях крестьяне вынуждены были вернуться к домашней выделке масла древним ручным способом. При этом они частично возобновляли работу уцелевших заводов и объединялись заново в традиционные крестьянские артели и товарищества на паях, что наблюдалось также в полеводстве и животноводстве. По данным статистики, в 1924 г. в России действовало несколько тысяч мелких разрозненных заводов, из них 90\% работали на ручном труде, 6,4\% имели конные приводы и лишь 0,6\% - водяные и паровые двигатели (Маслоделие 1932: 316).

В связи с наступившей в стране к этому времени стабилизацией внутренней обстановки правительством была поставлена задача создания пищевой индустрии, и в частности - крупной маслодельной промышленности. В 1924 г. был образован «Маслоцентр» по руководству единоличным и кооперативным маслоделием, а в 1930-м в Москве открылся Всесоюзный научно-исследовательский институт молочной промышленности (ВНИИМП) технического назначения по совершенствованию технологии производства. Одновременно началось строительство новых механизированных маслодельных заводов. Наступил период реконструкции и развития, оставлявший в стороне старинные народные традиции.

Для выполнения государственной программы развития маслоделия требовалось одновременно решить несколько серьезных и сложных задач: 1. Прежде чем запускать в производство новые заводы маслоделия, нужно было обеспечить их качественным 
сырьем в достаточном количестве, то есть поднять животноводство. 2. Заводы необходимо оснастить современной техникой отечественного производства, но не уступающей зарубежным. 3. Для выхода на международный рынок следовало добиться высокой гигиеничности всего производства, озаботиться улучшением вкусовых качеств в соответствии с современными запросами не только россиян, но и иностранных потребителей.

За годы оскудения России в западных странах бурно развивались различные отрасли промышленности. Производство концентрировалось в крупных населенных пунктах, преимущественно в городах. Их жители отрывались от сельской простоты, образ жизни изменялся, а с ним и вкусы населения обострялись и утончались. Горожане после длительной, напряженной работы с машинами нуждались в пище свежей, сытной и легкой, приятного вкуса и аромата, поданной в готовом к употреблению виде. По этим направлениям велась конкурентная борьба между производителями, соответственно усложнялись биржевые требования на международных рынках для экспортного масла. В основном они сводились к тому, чтобы продукт был высшего качества: свежий, чистый, однородный, принятого на рынках цвета, укупоренный в стандартную чистую, хорошо маркированную тару. Неисполнение одного из этих требований понижало рыночную цену масла и вообще отражалось на репутации товара. Важно также было, чтобы масло регулярно поступало на рынки в течение всего года. Согласно установленному стандарту, экспортное масло должно удовлетворять следующим требованиям: количество жира не менее $82 \%$ для соленого и 84\% для несоленого; воды в масле не выше 15,5\%; соли не выше 2\% (март-сентябрь 1,5\%, остальное время 1\%). Никаких консервирующих веществ, кроме поваренной соли, в масле не допускалось. Окрашивание масла разрешалось лишь специальной растительной краской. Масло должно быть укупорено в буковые бочонки весом нетто 50,8 кг, плюс на усушку в пути 0,4 кг, всего 51,2 кг. На днище каждого предназначенного к вывозу бочонка с маслом накладывали установленного образца трафарет (клеймо) с обозначением номера завода и бочонка, марки экспортирующей организации, веса. Бочонки обшивали в новую чистую рогожу, на которой ставили при отправке транспортные знаки (Маслоделие 1932: 321).

Россия в этих условиях оказалась в положении отстающей страны, и правительству необходимо было принять меры к изменению ситуации. Молодое советское государство озаботилось восстановлением скотоводства. В 1918 г. был издан декрет о племенном животноводстве, положивший начало работам по определению породности и в частности - по селекции. Хотя до революции начали проводить улучшение пород крупного рогатого скота, но это предпринимали отдельные владельцы усадеб или заводов, не было создано единой программы и эффективной методики.

В крестьянских хозяйствах содержанию скота уделяли мало внимания. В зимнее время животных держали в холодных помещениях, а в Сибири при крупных стадах - даже под открытым небом. Пастбища использовали лишь природные, не заботясь об их улучшении, хотя уже была доказана зависимость от кормов веса животных и молочности коров. Поэтому там, где имелись хорошие выпасы, появились, благодаря местному крестьянскому отбору, молочные породы рогатого скота.

В Советском Союзе прежде всего были определены конкретные направления работы по восстановлению животноводства. При проведении коллективизации животных из коопераций и от единоличников передавали в колхозы и совхозы. Фермы по содержанию молочного скота разделяли на молочные, мясо-молочные и мясные, первые из 
них размещали в местностях, где ранее процветало маслоделие. Племенную работу с молочными коровами начали, сохраняя традиции, на основе ранее отобранных крестьянами пород (холмогорская, архангельская, ярославская, курганская, сибирская и др.), которые улучшали путем скрещивания внутри страны и с привозными производителями. Дальнейшую работу определяло постановление правительства 1939 г. «О мероприятиях по развитию общественного животноводства в колхозах» (Крупный... 1953: 519-521). Племенную работу вели на основе правильного кормления, хорошего ухода за животными и учета продуктивности. Были созданы племенные совхозы и племенные рассадники, а также - заведены племенные книги по всем породам. Планировалось разместить породы по стране с тем расчетом, чтобы добиться бесперебойного снабжения заводов молоком в течение всего года. Эти меры должны были обеспечить рынок внутреннего потребления маслом и создать базу для экспорта, дававшего в прошлом значительное пополнение государственного бюджета.

Экспорт требовал увеличения выхода продукции через совершенствование технического оборудования и использования современных источников энергии. Для этого были подключены научные кадры ВНИИМП для улучшения технологии и введения механизации производства. В первую очередь были заменены традиционные деревянные маслобойки. Они оставались как бытовые элементы домашней утвари для получения свежего масла в течение всего ХХ в. Во вновь строящихся заводах устанавливали металлические маслоизготовители, работавшие на электродвигателе. По способу действия они разделялись на два вида: прерывного действия и непрерывного. Основной частью аппаратов была укрепленная горизонтально бочка. Первый вид аппарата был более сходен по принципу работы с традиционной маслобойкой, так как его останавливали для промывки маслокомков, а затем их отжимали от воды путем быстрого вращения. В аппарат непрерывного действия был вмонтирован еще один цилиндр, в котором масляные комки при вращении отжимались и перемешивались, на выход поступал непрерывный пласт готового масла. Еще более совершенным был аппарат, в котором соединены непрерывной цепочкой весы, приемный бак, пастеризатор, сепаратор и сбиватель, а в завершение цепи - охладитель масла, из него масляная лента поступала непосредственно в тару. Машина имела высокую производительность и обеспечивала гигиену процесса. В продолжение механизации были созданы фасовочные автоматы. Они разделяли поток масла на порции заданного веса и формы, затем передавали в аппарат на завертывание в пергаментную ленту, автоматически прокомпостированную с указанием названия, сорта и веса. Эти агрегаты имели разные формы и несколько различались по устройству, но все действовали по одному назначению - освобождение от ручного труда, ускорение темпов производства и повышение его стерильности, но вместе с тем автоматы выводили маслоделие из традиционной области знаний и переводили его в индустриальное производство (Масло 1954: 432, 436).

Государство ставило перед производством задачу выйти на международный рынок и добиться тех же высоких мест, которые были достигнуты в начале XX века. Необходимым условием для этого было соблюдение ряда требований. Россия никогда не делала различий между внутренним и внешним рынком. Хотя в стране экспорт сочетался с импортом, ввозили зарубежные образцы, но развивали в первую очередь собственное производство и поддерживали отечественные бренды, сложившиеся в начале XX в. На этом, завершающем периоде производства на первый план вышли 
народные традиции. В России производили развесное масло кратковременного хранения из молока, сливок (сладкосливочное) и сметаны (кислосливочное), а также перетопленное масло длительного хранения - русское (или топленое), пользовавшееся на мировом рынке большой популярностью. В XX в. кисломолочное масло улучшилось по качеству, так как заквашивание стали производить с помощью кисломолочных бактерий, что избавляло от случайного попадания других веществ. Однако спрос на этот вид масла на мировом рынке уменьшился и потребовалось больше производить сладкосливочного масла. Для продления срока хранения оба вида масла начали подсаливать, по международным нормам не более, чем на $2 \%$, а топленое масло в этом не нуждалось. Проверку на экспорт проходили, также, по жирности и влажности. От этого в традиционных видах продуктов появились варианты: во всех соленых маслах допускали жирность до 81\%, в несоленых - до 83\%, а влажность соответственно до $16 \%$ в соленых и $10 \%$ в несоленых. Топленое масло имело самую высокую жирность 98\%, и лишь 1\% влажности. В советском производстве появился еще любительский вид несоленого масла, в котором могло быть повышенное содержание влаги (до 20\%) за счет уменьшения жирности. Для внутреннего рынка сладкосливочные масла стали производить с наполнителями (с ягодами и соками, с какао и кофе, с медом, сахаром и пр.), что увеличивало разнообразие товаров.

Вместе с тем, для сохранения русских брендов на мировом рынке, государство развивало лучшие дореволюционные производства, организуя областные центры молочной промышленности. Так, в Вологодской обл. непрерывно действовали заводы, открытые еще Н. Верещагиным по производству сладкосливочного масла из подогретых или оттопленных сливок, реконструированные и оснащенные современным для того времени оборудованием. «Вологодское масло» из молока коров ярославской породы было оценено, как лучшее в стране, по вкусу, легкости и аромату. Аналогичный центр, работавший на молоке высокомолочной коровы местной породы, был сохранен и получил развитие в Костромской обл. Сибирь и в ХХ в. поставляла масла больше, чем в европейской части страны. В этом регионе в Курганской обл., где был организован и действовал Союз Сибирских маслоделов, продолжали работу заводы на сырье от местной кунгурской породы коров. Еще более известен был Алтайский центр по производству масла из молока сибирской коровы, сохранявшей более высокую жирность. Лучшие виды отечественного масла, как и раньше, поступали на экспорт, но ситуация на мировом рынке к концу ХХ в. существенно изменилась. В ряды экспортеров, наряду с прежними вступили новые игроки (Новая Зеландия, Индия и др.), специализировавшиеся на том же производстве. Советская Россия основное внимание уделяла распространению маслозаводов во все регионы своей страны и к повсеместному снабжению торговой сети масла-молочной продукцией промышленного производства.

Параллельно с общественным, развивалось и домашнее маслоделие, перенимая кое-что от промышленного. В быт сельчан вошла утварь, уже давно использовавшаяся в городах: стеклянная, керамическая, металлическая, в том числе эмалированная, сохранялась также и прежняя гончарная. «Раньше были гончарные кринки» - вспоминала в 1965 г. жительница с. Екатерининского. - «Их возили гончары и продавали по деревням. Теперь молоко держат в стеклянных кринках» (ПМА 11: Лопатина). Во второй половине XX в. все крестьянские семьи, державшие коров, имели также и сепараторы, ускорявшие разделение молока на фракции. Пожилые женщины, 
нередко продолжали делать масло в избах, молоко пропускали через сепаратор. «Сливки сквашиваем в сметану и оттапливаем в печи, пока не свернутся, примерно с полчаса, потом сыворотку сливаем, протыкаем ложкой. Потом отбрасываем густое в кастрюлю и мешаем веселкой» (ПМА 12: Ефимова). С конца ХІХ в., после распространения переносных сепараторов, крестьянки стали делать сладкомолочное масло из сливок, которые не сквашивали, а сливали в маслобойки. Эти бондарные приборы также изменялись. М.С. Лопатина отметила последовательность смены форм. «Сметану сбивали раньше в масленочке - бондарной кадочке, широкой как квашня. В ней сбивали рукой. Потом стали делать туесочки бондарные с крестовиной, а потом, как у нас - маслобойки - ящичком, в нем крестовина, а сбоку ручка, чтобы крутить» (ПМА 13: Лопатина). Все названные варианты использовали до конца XX в., народные традиции пополнялись и продолжали существовать.

$* * *$

Подводя итог рассмотрению истории русского народного и промышленного маслоделия, прежде всего следует отметить участие в их развитии всех слоев общества, что привело к созданию конкурентно способного производства, достигшего к началу XX в. высоких показателей в мировом экспорте. На этом пути выявлено насколько последовательных периодов.

I. Крестьянско-традиционный. Народные способы получения масла из коровьего молока создавались вековой практикой пользования. Естественная природа молока определила основные моменты производства, сходные у разных народов Европы, однако его детали приобрели этнические особенности. Традиции изготовления масла в нашей стране были сформированы русскими женщинами-хозяйками с использованием тепла русской печи, ими же был найден способ получения конечного продукта длительного хранения - топленого масла, составившего специфику народного маслоделия. Женщины выполняли всю работу руками. Они же определяли формы используемой глиняной утвари. Весь процесс изготовления топленого масла занимал больше недели, а выход конечного продукта был невелик. Тем не менее во второй половине XIX в. масло приобрело товарное значение.

II. Начало промышленного производства. В России обратились к промышленному производству лишь во второй половине XIX в., когда в других странах Западной Европы его продукция не только удовлетворяла потребности жителей, но и частично вывозилась в другие страны. В России инициаторами промышленного маслоделия стали представители дворянской интеллигенции, увидевшие за границей значительное улучшение жизни крестьян, принявших машинный способ получения масла. Группа, возглавленная Н. Верещагиным, поставила целью обучение русских крестьян, открыв школу маслоделия и построив на свои средства первые заводы по производству сыра и масла на импортном оборудовании с привлечением иностранных специалистов.

Дело быстро распространялось в губерниях европейской части страны, благодаря поддержке его ВТО, губернскими и земскими управами. Вырастали российские мастера, открывались крестьянские артельные и частные заводы землевладельцев. Возникли местные центры маслоделия (Вологодская, Костромская губ.). Отечественное масло вошло в товарный оборот во внутреннем рынке и опробировалось на внешнем.

III. Маслоделие в Сибири. Развитие экспорта. Сибирские крестьяне держали по многу коров, поэтому домашнее маслоделие превышало потребности семьи, и масло 
через посредство скупщиков поступало на ярмарки. Появление в конце XIX в. переносного сепаратора ускорило выделение сливок, что позволило крестьянам устраивать примитивные заводы в своих домах.

Развитие товарного маслоделия значительно ускорилось после создания Союза Сибирских маслоделов в нач. XX в. Его усилиями было поставлено обучение крестьян в школах маслоделия с выездом за рубеж для получения практики. Союз руководил организацией артелей для промышленного производства масла, помогал с приобретением оборудования, налаживал транспортировку продукции, строил маслохранилища и установил международные связи для экспорта. Сибирское маслоделие превзошло результаты его в европейской части страны. За рубежом высоко оценили качество топленого сибирского масла, присвоив ему название «русское». Оно успешно завоевало первые места на мировом экспортном рынке.

IV. Советский период в маслоделии. Сложный период длительных военных действий в нач. XX в., затем перемена государственного строя подорвали хозяйство страны, пострадало и маслоделие. Многие заводы были экспроприированы, значительное число их разорено, подорвана также и сырьевая база. Молодому советскому государству пришлось начинать восстановительную работу сразу по нескольким направлениям. Государство начало с объединения уцелевших заводов под своим управлением для реконструирования, оно же отстраивало новые заводы по современной для того времени технологии. Одновременно наращивали стадо молочного скота, улучшали породность, обеспечивая круглогодичное снабжение заводов. За вторую половину XX в. были выведены новые сорта и виды масломолочной продукции, проведена индустриализация производства, налажено бесперебойное и повсеместное снабжение населения.

\section{Список сокращений}

АК - Алтайский край.

БСЭ - Большая советская энциклопедия.

ВКО - Восточно-Казахстанская обл.

ВНИИМП - Всесоюзный научно-исследовательский институт молочной промышленности. ВЭО - Вольное экономическое общество.

ИЭА РАН - Институт этнологии и антропологии Российской Академии наук.

ПМА - Полевые материалы автора.

ССМ - Союз сибирских маслоделов.

ССЭ - Сибирская советская энциклопедия.

\section{Источники и материалы}

Верещагин 1896а - Верещагин Н.В. К вопросу о русском молочном скоте (1880-1894), совместно с Поповым А.А., М., 1896.

Верещзагин $1896 б$ - Верещагин Н.В. О мерах к развитию молочного хозяйства на артельных началах // Гутерц А.В. Николай Верещагин. На благо отечества. Вологда, 2011.

Даль 1911 - Даль В.Н. Толковый словарь живого великорусского языка. Т. 2, Т. 3., М. 1911.

Дерунов 1877 - Дерунов С. Сливочное масло и его производство в Пошехонском уезде (Корреспорнедция «Вестника Ярославского земства») // Вестник Ярославского земства. 1877. № 1-2. Ярославль.

Животноводство 1929 - Животноводство // ССЭ. Т. 1. [1929].

Зеленин 1991 - Зеленин Д.К. Восточнославянская этнография. М., 1991.

Иванов 1895 - Иванов П. По поводу маслоделия в великорусской северной губернии. Пошехонье, 1895. 
Крупный... 1953 - Крупный рогатый скот БСЭ, Т. 23. [1953].

Масло 1954 - Масло // БСЭ. Т. 26. [1954].

Масло 1991 - Масло // Даль В.И. Толковый словарь живого великорусского языка. Т. 3, М., 1991.

Маслоделие 1932 - Маслоделие // ССЭ. Т. 3 [1932].

Масляная... 1932 - Масляная торговля // ССЭ. Т. 3 [1932].

Снегирев 1906 - Снегирев Д. О маслоделии // Псковские губернские ведомости, № 15. 1906.

Сокульский 1896 - Сокульский В.Ф. Производство сибирского масла // Тобольские губ. ведомости (отд. оттиск), 1896.

Тамбовская... 2004 - Тамбовская энциклопедия. Тамбов, 2004.

Чистяков 2015 - Чистяков В. Лейтенант флота в отставке // Под самым прекрасным флагом. М., 2015.

ПМА 1 - Полевые материалы автора. Экспедиция в Тамбовскую обл., август 2004 г. Личные наблюдения.

ПМА 2 - Полевые материалы автора. Выезд в Рязанскую обл., август 1941 г., выезд в Казахстан, лето 1943 г. и др.

ПМА 3 - Полевые материалы автора. Экспедиция в Алтайский край, сентябрь 1980 г. (Информант Петрова А.Т., 1918 г.р.).

ПМА 4 - Полевые материалы автора. Экспедиция в Алтайский край, июль 1988 г. (Информант Горбунова А.И., 1984 г.р.).

ПМА 5 - Полевые материалы автора. Экспедиция в Алтайский край, июль 1988 г. (Информант Горбунова А.И., 1984 г.р.).

ПМА 6 - Полевые материалы автора. Экспедиция в Алтайский край, август 1965 г. (Информант Матвеева Т., 1905 г.р.).

ПМА 7 - Полевые материалы автора. Экспедиция в Алтайский край, сентябрь 1980 г. (Информант Петрова А.Т. 1918 г.р.; экспедиция 1970 г. Информант Сапраскина О. 1937 г.р. и др.).

ПМА 8 - Полевые материалы автора. Экспедиция в ВКО, июль 1979 г. (Информант Лопатина М.С., 1905 г.р.; Личные наблюдения автора 1960-1990 г.г.).

ПМА 9 - Полевые материалы автора. Экспедиция в ВКО, август 1980 г. (Информант Авдеев B.A., 1887 г.р.).

ПМА 10 - Полевые материалы автора. Экспедиция в Алтайский край, июль 1965 г. (Информант Демченко М.А., 1924 г.р.).

ПМА 11 - Полевые материалы автора. Экспедиция в ВКО, июль 1980 г. (Информант Лопатина М.С., 1905 г.р.).

ПМА 12 - Полевые материалы автора. Экспедиция в Алтайский край, август 1965 (Информант Ефимова Т., 1914 г.р.),

ПМА 13 - Полевые материалы автора. Экспедиция в ВКО, июль 1980 г. (Информант Лопатина М.С., 1905 г.р.).

\section{Научная литература}

Бардина П.Е. 2009. Быт и хозяйство русских сибиряков Томского края. Северск: «Контекст». Богоявленский Н.A. 1960. Древнерусское врачевание в XI-XVII вв. М.: «Медицинская литература».

Руденко С.И. (ред.) 1930. Бухтарминские старообрядцы. Л.: изд-во АН СССР.

Гутери А.В. 2011. Николай Верещагин. На благо отечества. Т. 1-2. Вологда: Вологжанин.

Lipinskaya, Victoria A.

\section{Russian Butter Making (Tradition and Innovation), XIX-XX cc.}

DOI: $10.33876 / 2311-0546 / 2021-53-1 / 238-259$

Russian butter making developed in XIX-XXcc. as a public effort involving all strata of the society. This effort helped create industrial production of the highest international level. The 
article defines consequent periods of this process.

1. Russian butter-making was based on national traditions of obtaining butter from cow's milk, which were ethnically specific. The specificity was determined by the climate with long winters, during which the lactation of cattle ceased, which required preparing food supplies. Women were responsible for this in the peasant economy. They practiced various methods of obtaining butter, including the final product-ghee, which was processed by the heat of a Russian stove and could be stored during unlimited period.

2. The pioneer of the development of commercial butter-making was N.V. Vereshchagin. He studied the technology of obtaining butter in rural artels of different states and set the goal to introduce this experience in Russia to improve the life of the peasantry. Overcoming the resistance of officials and involving like-minded people, he opened public schools and butter-making factories using local experience.

3. The work intensified in Siberia, where peasants owned large herds of dairy cattle. The Unions of Butter Makers played an important role organizing artels, providing the storage and delivery of goods, establishing connections with the international market, where Russian butter surpassed other exporters.

4. During the Soviet period, the development of butter-making at the state level began. The industrial production was organized in a consistent and multifaceted manner: the selection work of livestock breeders was combined with the preservation of ethnic specificity and the strengthening of the traditional base of dairy raw materials, while technical institutes developed modern equipment, so the quality of the product improved and it was abundantly supplied to the trade network.

Keywords: butter making, national traditions, ethnic specifics, industrial production, transformations of the Soviet period

For Citation: Lipinskaya, V.A. 2021 Russian Butter Making (Tradition and Innovation), XIX-XX cc. Herald of Anthropology (Vestnik Antropologii) 1 (53): 238-259.

*Lipinskaya, Victoria A. - Dr. of Hist, Leading researcher, Institute of Ethnology and Anthropology RAS (Moscow, Leninski prosp., 32a). E-mail: vlipinskaya@yandex.ru

The research is published as part of the Research Plan of the Institute of Ethnology and Anthropology (Russian Academy of Sciences, Moscow)

\section{References}

Bardina P.E. 2009. Byt i khoziaistvo russkikh sibiriakov Tomskogo kraia [Life and economy of Russian Siberians in Tomsk Territory]. Seversk: "Kontekst'.

Bogoiavlenskii N.A. 1960. Drevnerusskoe vrachevanie v XI-XVII vv. [Old Russian healing in the XI-XVII centuries]. M.: "Meditsinskaia literatura'.

Rudenko S.I. (ed.) 1930. Bukhtarminskie staroobriadtsy [Bukhtarma Old Believers]. L.: izd-vo AN SSSR.

Guterts A.V. 2011. Nikolai Vereshchagin. Na blago otechestva [Nikolai Vereshchagin. For the good of the fatherland ]. T. 1-2. Vologda: Vologzhanin. 
(C) Н.Л. Пушкарева, И.В. Богдашина

\section{«ВКУСНАЯ И ЗДОРОВАЯ ПИЩА» В ПОВСЕДНЕВНЫХ ЖЕНСКИХ ПРАКТИКАХ НЕСТОЛИЧНОГО СОВЕТСКОГО ГОРОДА 1950-1960-х ГГ.}

Советская женская повседневность в 1950-1960-х г2. редко бывает предметом пристального этнографического наблюдения. В иентре внимания данной статьи - ее такая важная сторона, как приобретение и заготовка продуктов питания, а именно вопросы, связанные с приготовлением пищи, обеспечением едой детей, родных и близких в условиях возрождавшегося после войны хозяйства Волгограда. Обращение к эго-документам крупного нестоличного региона Нижнего Поволжья позволило выявить и сравнить общее и особенное в повседневно-бытовых практиках приготовления пищи, уяснить отношение самих женщин к предпринимаемым государством попыткам облегчить их домашний труд как хозяек, выявить полулегальные (получение в обход очереди, из-под прилавка) и противозаконные (блат) способы «накармливания» своих семей. По мнению авторов, в условиях скрытого дефицита товаров женщины сталкивались со многими трудностями (очереди, нехватки, лишения), но неся бремя нескончаемых домашних дел, считали порой время, затраченное на них, формой отдыха и досуга. Домамнее, а не общественное питание, бьло основной формой потребления в провинциальном городе Нижнего Поволжья. Жительниць этого города, совмещуая множество социальных ролей, неся двойную нагрузку (на работе и дома), ежедневно выполняли свои обязательства, нанося ущерб профессиональным перспективам, здоровью, отдыху и, не осознавая этой дискриминации, продолжали выполнять вмененные им обществом традиционно «женские» домашние обязанности.

Ключевые слова: гендерная антропология, женский домашний труд, приготовление пищи, потребление, «хрущевская оттепель», Волгоград

Ссылка при цитировании: Богдашина И.В., Пушкарева Н.Л. «Вкусная и здоровая пища» в повседневных женских практиках нестоличного советского города 1950-1960-х гг. // Вестник антропологии, 2021. № 1 (53). С.

Повседневность - сфера человеческой обыденности, в которой приобретение продуктов и их приготовление, забота о соблюдении режима питания для себя и

Пушкарева Наталья Львовна - д.и.н., главный научный сотрудник, зав. центром гендерных исследований, Институт этнологии и антропологии им. Н.Н. Миклухо-Маклая РАН (119991 Москва, Ленинский просп., 32а. Эл. почта: pushkarev@mail.ru

Богдашина Ирина Владимировна - аспирант, Институт этнологии и антропологии им. Н.Н. Миклухо-Маклая РАН (Москва, Ленинский пр. 32А). Эл. почта: ira18bogdashina@mail.ru

*Подготовлено по плану НИР ИЭА РАН и проекту РФФИ № 19-09-00191 «Женская социальная память как консолидирующий потенциал многопоколенной семьи, укрепления государственности и российской нации (18-21 век)» 